\title{
PARASITOIDS AND HYPERPARASITOIDS OF APHELINIDS (HYMENOPTERA: APHELNIDAE) ASSOCIATED WTH ARMORED SCALE, SOFT SCALE INSECTS (HEMIPTERA: COCCOIDEA) AND WHITEFLIES ( HEMIPTERA: ALYERODOIDEA) ON OLIVE IN EGYPT \\ Nadia A. Aly \\ Plant Protection Research Institute, Agricultural Research Center, Dokki, Giza, Egypt.
}

\begin{abstract}
Aphelinids (Hymenoptera : Aphelinidae) are the most important parasitoids of, armored scale, soft scale insects ( Hemiptera: Coccoidea) and whiteflies ( Hemiptera: Alyerodoidea). The present work dealt with the diagnosis and abundance and the role of this group in controlling armored scale, soft scale insects and whiteflies. The results indicated that 17 parasitoids and hyperparasitiods were reared from samples of armored, soft scale insects and whiteflies in different locations in Egypt. These parasitoid and hyperparasitiod species were collected from 7 armored, soft scale insects and whiteflies and distributed in 5 Governorates (Alexandria, Assuit, Ismailia, Fayoum and Matruh). The maximum rate of parasitism of armored scale insects parasitoids ranged between $12-59 \%$ during the two years under consideration. While the maximum rate of parasitism of soft scale insects and whiteflies parasitoids ranged between $13-28 \%$ and $39-58 \%$, during the two years under consideration, respectively. This result indicated that some parasitoids of armored, soft scale insects and whiteflies were effective in controlling them.
\end{abstract}

\section{INTRODUCTION}

Armored scale insects (Hemiptera : Diaspididae) excrete honeydew, a sweet, sticky liquid produced by sucking insects that ingest large quantities of plant sap. Sticky honeydew and the blackish sooty mold growing on honeydew can bother people even when scale populations are not harming plants. When plants are heavily infested with scales, leaves may look wilted, turn yellow, and drop prematurely. Scales sometimes result in curl leaves or cause deformed blemishes or discolored halos in fruit, leaves, or twigs. Bark infested with armored scales may crack and exude gum. Certain armored scales also feed on fruit, but this damage is often just aesthetic (Abd-Rabou, 2003a).

Soft scales (Hemiptera : Coccidae) infest leaves and twigs but rarely feed on fruit. A major concern with soft scales is their excretion of abundant honeydew, which contaminates fruit, leaves, and surfaces beneath plants. Honeydew encourages the growth of black sooty mold and attracts ants, which in turn protect scales from natural enemies. When found in numerous abundance, some scale species weaken plants and cause them to grow slowly. Branches or other plant parts may die if they remain heavily infested with scales. If plant parts die quickly, dead brownish leaves may remain on branches, giving them a scorched appearance. Several years of severe 
infestations may kill young plants. Soft scales reduce plant vigor, but seldom kill trees or shrubs (Gill, 1997).

Whiteflies (Hemiptera : Aleyrodidae) injure olive plants by consuming large quantities of sap, which it obtains with its sucking mouth parts. Further indirect injury is caused by sooty mold fungus which grows over fruit and foliage in the copious amount of honeydew excreted by the whitefly. This black fungus may cover the leaves and fruit so completely that it interferes with the proper physiological activities of the trees. Heavily-infested trees become weak and produce small crops of insipid fruit. Only three species of whiteflies have been recorded attacking olive trees in Egypt (Abd-Rabou, 2001b). These are Aleurolobus olivinus (Silvestri) (Abd-Rabou, 1996), Bemisia tabaci (Gennadius) (Abd-Rabou, 1997) and Siphoninus phillyreae (Haliday) (Hemiptera : Aleyrodidae) (Abd-Rabou, 2003 b).

Parasitic wasps are often the most important natural enemies of scales and whiteflies. Parasitoids include many species of Aphytis spp., Coccophagus spp., Encarsia spp., Eretmocerus spp. (Hymenoptera : Aphelinidae) and Metaphycus spp. ((Hymenoptera : Encyrtidae) (Dreistadt et al.,2004).

The aim of this work is to study the diagnosis, abundance and the role of aphelinids in controlling armored scale, soft scale insects and whiteflies.

\section{MATERIALS AND METHODS}

A preliminary survey was conducted during 2013-2014 on different host plant infested by different species of armored scale, soft scale insects and whiteflies in Egypt to determine the presence of these pests. In the mean time through this survey the distribution of the aphelinid parasitoids and hyperparasitoids associated with armored scale, soft scale insects and whiteflies. Another survey conducted also during $2013-2014$ in 5 governorates to determine the impact of the parasitoids and hyperparasitoids on existing in armored scale, soft scale insects and whiteflies.

Samples of various armored, soft scale insects and whiteflies were collected to study the population dynamics of aphelinids on olive (Olea europaea). The selected plants for the present investigation did not receive any chemical control for several years ago before this study. The samples were collected half monthly from in Alexandria, Assuit, Ismailia , Fayoum and Matruh. Each leaf was stored in a well-ventilated emergency glass tube and monitored daily for the emergence of parasitoids.

All armored, soft scales and whiteflies found on the whole area of each leaf were counted and recorded. The parasitism rate was determined by dividing the number of emerging parasitoids by the number of hosts. 


\section{RESULTS AND DISCUSSION}

1.List of aphelinid parasitoids and hyperparasitoids associated with armored scale, soft scale insects and whiteflies in Egypt:

1.1. Ablerus aegypticus Abd-Rabou

1.2. A. atomon (Walker)

1.3. Aphytis chrysomphali (Mercet)

1.4. A. diaspidis (Howard)

1.5. A. libanicus Traboulsi

1.6. Aphytis matruhi Abd-Rabou

1.7. A. maculicornis (Mercet)

1.8. A. paramaculicornis De Bach \& Rosen

1.9. Coccophagoides aegypticus Abd-Rabou

1.10. Coccophagus cowperi Girault

1.11. C. Iycimnia (Walker)

1.12. C. scutellaris (Dalman)

1.13. Encarsia aurantii (Howard)

1.14. E. citrina (Craw)

1.15. E. inaron (Walker)

1.16. E. olivina (Masi )

1.17. Marietta leopardina Motschulsky

2.Armored scale, soft scale insects and whiteflies of aphelinid parasitoids and hyperparasitoids hosts of olive in Egypt:

2.1. Armored scale insects:

2.1.1. Hemiberlesia lataniae (Signoret).

2.1.2. Leucaspis riccae Targioni -Tozzetti.

2.1.3. Parlatoria oleae (Colvée).

2.2. Soft scale insects:

2.2.1. Saissetia oleae Olivier.

2.2.2. Saissetia coffeae (Walker).

2.3. Whiteflies:

2.3.1. Aleurolobus olivinus (Silvestri)

2.3.2. Siphoninus phillyreae (Haliday)

3. Diagnostic and abundance of aphelinid parasitoids and hyperparasitiods in different locations on olive in Egypt:

Ablerus aegypticus Abd-Rabou

Diagnosis: Antennal scape more than 3 times as long as broad, Third funicle segement as long as wide, Club 3.5 times as long as wide. mesoscutum about 1.8 times as long as wide and Marginal fringe 0.5 as long as the width of disc. Mid tibial spur about 1.3 times as long as basitarsus.

Abundance: Only 30 individuals were collected associated with $H$. lataniae in Alexandria during the two years under consideration (Table,1).

Remarks: This species described and recorded in Egypt for the first time by Abd-Rabou (2014).

Ablerus atomon (Walker)

Diagnosis: Antenna 7 -segmented $(1,1,4,1)$, first funicle segment 3 times as long as wide, third funicle segment 1.5 times as long as wide; submarginal 
vein with one setae, marginal fringe 1.6 times as long as the width of disc; mesoscutum 2-4 pairs of setae.

Abundance: Only 28 individuals were collected associated with $H$. lataniae in Ismailia during the two years under consideration (Table,1).

Remarks: This species was recorded for the first time in Egypt associated with C. stantophri by Abd-Rabou (1999).

Aphytis chrysomphali (Mercet)

Diagnosis:. This is a cosmopolitan and uniparental species. Thoracic setae paler, thoracic sterna faintly dusky, with a conspicuous longitudinal median black line on the stem of mesosternal furca. Antennae slender; propodum 0.7 as long as scutellum, 6 times as long as metanotum; non overlapping crenulae.

Abundance: The parasitism was observed for $A$. chrysomphali on $H$. lataniae infesting O.europaea at Ismailia. Maximum rate of parasitism reached 22 and $45 \%$ with means of 12.7 and $20.7 \%$ over 2013 and 2014 , respectively. Dates of maximum activity were June 2013 and 2014. The seasonal activity of this parasitoid on $\mathrm{H}$. lataniae is presented in (Table,1 and Fig. 1).

Data in Table (2), showed that the simple correlation between percent parasitism of parasitoid, $A$. chrysomphali and the mean number of $H$. lataniae were positive $(r=0.59376$ and 0.55724$)$ were significant,during 2013 and 2014, respectively. On the other hand, results in Table (2), showed that the simple regression for changing the percent parasitism of parasitoid, A. chrysomphali on the mean number of $H$. lataniae were positive $(b=2.33$ and 2.12) were significant, during 2013 and 2014, respectively.

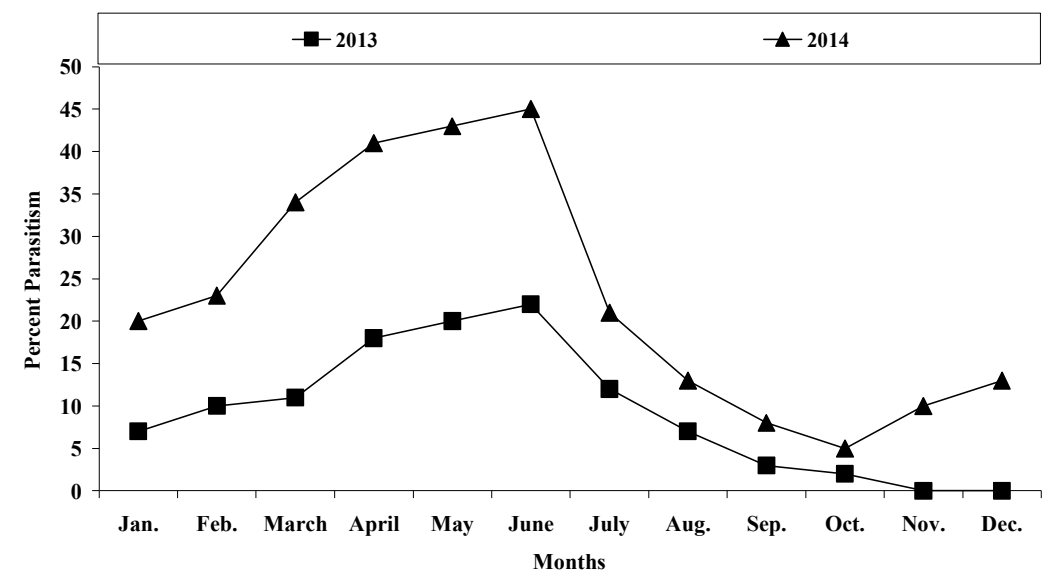

Fig. (1): Percent parasitism of Aphytis chrysomphali associated with Hemiberlesia lataniae infested olive in Ismailia during 2013 and 2014. 
J. Plant Prot. and Path., Mansoura Univ., Vol.6 (4), April, 2015 
Table (2): Simple correlation and regression values of the population dynamics of insect and its parasitoids within 2013 and 2014.

\begin{tabular}{|l|c|c|c|c|}
\hline Variable & $\begin{array}{c}\text { Simple } \\
\text { correlation } \\
\text { "r" }\end{array}$ & $\begin{array}{c}\text { Probability } \\
\text { "P" }\end{array}$ & Regression & $\begin{array}{c}\text { Probability } \\
\text { "P" }\end{array}$ \\
\hline $\begin{array}{l}\text { Percent } \\
\text { parasitism. 2013 }\end{array}$ & 0.59376 & 0.0418 & 2.33 & 0.0418 \\
\hline $\begin{array}{l}\text { Percent } \\
\text { parasitism. 2014 }\end{array}$ & 0.55724 & 0.0598 & 2.12 & 0.0598 \\
\hline
\end{tabular}

Remarks: This species was recorded for the first time in Egypt by AbdRabou and Hayat (2003). About 13000 individuals of A.chrysomphali was released on olive trees infested by P.oleae in Northeren Coast, the parasitism rates reached maximum 11\% ( Abd-Rabou, 2001e). Abd-Rabou (2000) recorded the parasitoid, associated with five armored scale insects in different locations in Egypt.

\section{Aphytis diaspidis (Howard)}

Diagnosis: This is biparental and uniparental. Occiput with a fuscous to black bar on each side of foramen, the mouth margin and malar sulcus fuscous. Gaster uniformly fuscous or dusky dorsally, with distinct darker cross-bands on terga. Pedicel and flagellum rather uniformly fuscous, tip of club usually blackish, 7 sensilla.Mesoscutum with 16 setea, crenulae usually wider, more rounded and 6 non overlapping. The relative length of the ovipositor 1.3 times as long as midtibia.

\section{Abundance:}

The parasitism was observed for $A$. diaspidis on P.oleae infesting O.europaea at Ismailia. Maximum rate of parasitism reached 30 and $55 \%$ with means of 10.6 and $27.8 \%$ over 2013 and 2014, respectively. Dates of maximum activity were May 2013 and 2014. The seasonal activity of this parasitoid on P.oleae is presented in (Table,1and Fig. 2). Data in Table (3), showed that the simple correlation between percent parasitism of parasitoid, A. diaspidis and the mean number of $P$.oleae were positive $(r=0.64360$ and 0.8779) were significant and highly significant,during 2013 and 2014, respectively. On the other hand, results in Table (3), showed that the simple regression for changing the percent parasitism of parasitoid, $A$. diaspidis on the mean number of P.oleae were positive $(b=2.66$ and 5.79) were significant and highly significant, during 2013 and 2014, respectively. 


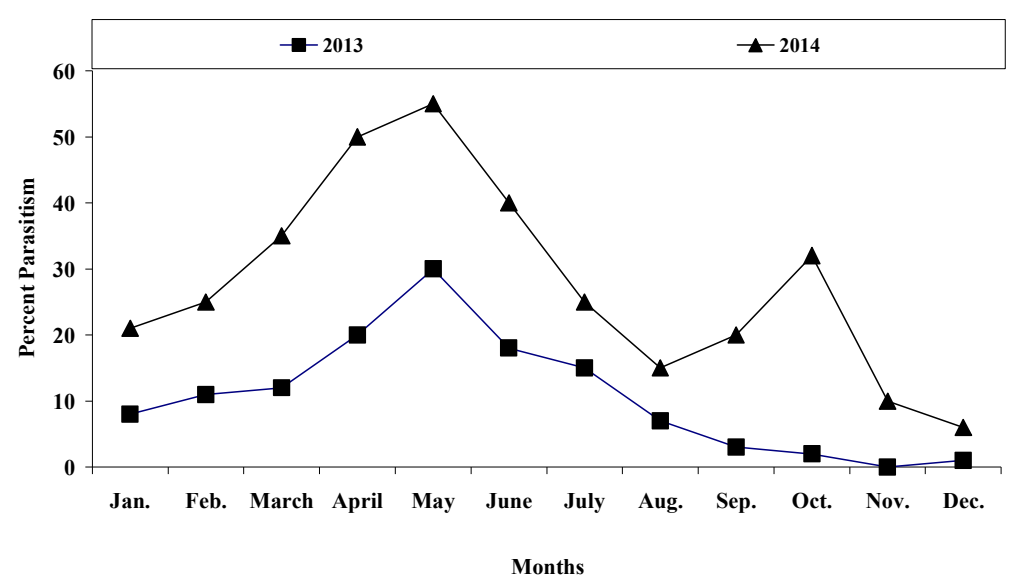

Fig. (2): Percent parasitism of Aphytis diaspidis associated with Parlatoria oleae infested olive in Ismailia during 2013 and 2014. .

Table (3): Simple correlation and regression values of the population dynamics of insect and its parasitoids within 2013 and 2014.

\begin{tabular}{|l|c|c|c|c|}
\hline Variable & $\begin{array}{c}\text { Simple } \\
\text { correlation } \\
\text { "r" }\end{array}$ & $\begin{array}{c}\text { Probability } \\
\text { "P" }\end{array}$ & Regression & $\begin{array}{c}\text { Probability } \\
\text { "P" }\end{array}$ \\
\hline $\begin{array}{l}\text { Percent } \\
\text { parasitism. } \\
2013\end{array}$ & 0.64360 & 0.0239 & 2.66 & 0.0239 \\
\hline $\begin{array}{l}\text { Percent } \\
\text { parasitism. } \\
2014\end{array}$ & 0.87779 & 0.0002 & 5.79 & 0.0002 \\
\hline
\end{tabular}

Remarks: This species was recorded for the first time in Egypt by Priesner \& Hosny (1940). The maximum parasitism rate of $A$. diaspidis on P.oleae on $O$. europaea in Northeren Coast was $26.1 \%$ during May, with an average rates 7.9\% (Abd-Rabou,2001e).

Aphytis libanicus Traboulsi

Diagnosis:. This is Mediterranean and biparental species. Occiput without such bars on sides of foramen, mouth margin and malar sulcus usually not fuscous. Propodeal crenulae short, non-overlapping; positoer margin of scutellum pale as rest of scutellum; thoracic setae paler; ovipositor stylets about 1.8 times as long as mid tibia. Mososcutum 11 setae and marginal fringe 0.2 as long as width of disc.

Abundance: The parasitism was observed for $A$. libanicus on $L$. riccae infesting O.europaea at Fayoum. Maximum rate of parasitism reached 29 and $33 \%$ with means of 18.7 and $18.4 \%$ over 2013 and 2014, respectively. Dates of maximum activity were November 2013 and May 2014, 
respectively. The seasonal activity of this parasitoid on L. riccae is presented in (Table,1and Fig. 3).

Data in Table (4), showed that the simple correlation between percent parasitism of parasitoid, $A$. libanicus and the mean number of $L$. riccae were positive ( $r=0.48027$ and 0.70357$)$ were non-significant and significant,during 2013 and 2014, respectively. On the other hand, results in Table (4), showed that the simple regression for changing the percent parasitism of parasitoid, $A$. libanicus on the mean number of $L$. riccae were positive $(b=1.73$ and 3.13) were non-significant and significant, during 2013 and 2014 , respectively.

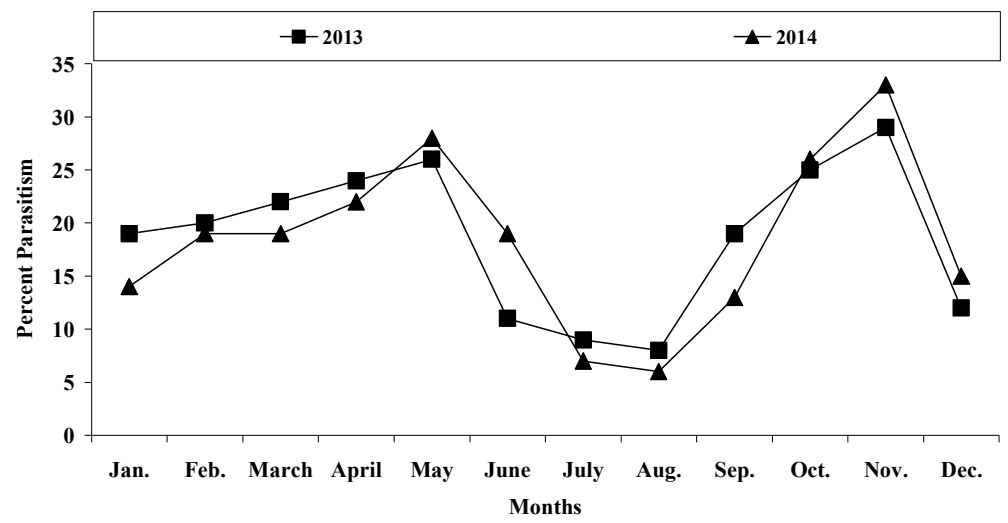

Fig. (3): Percent parasitism of Aphytis libanicus associated with Leucaspis riccae infested olive in Fayoum during 2013 and 2014.

Table (4): Simple correlation and regression values of the population dynamics of insect and its parasitoids within 2013 and 2014.

\begin{tabular}{|l|c|c|c|c|}
\hline Variable & $\begin{array}{c}\text { Simple } \\
\text { correlation } \\
\text { "r" }\end{array}$ & $\begin{array}{c}\text { Probability } \\
\text { "P" }\end{array}$ & Regression & $\begin{array}{c}\text { Probability } \\
\text { "P" }\end{array}$ \\
\hline $\begin{array}{l}\text { Percent } \\
\text { parasitism. } \\
2013\end{array}$ & 0.48027 & 0.1140 & 1.73 & 0.1140 \\
\hline $\begin{array}{l}\text { Percent } \\
\text { parasitism. } \\
2014\end{array}$ & 0.70357 & 0.0107 & 3.13 & 0.0107 \\
\hline
\end{tabular}

Remarks: Abd-Rabou and Hayat (2003) recorded this species for the first time in Egypt. The maximum parasitism rates of $A$. libanicus on $L$. riccae on O. europaea in Fayoum was $28.6 \%$ during Nov. with an average rates $6.8 \%$ (Abd-Rabou, 2001e). 


\section{Aphytis maculicornis (Mercet)}

Diagnosis: This is palearctic and uniparental species. Occiput with a fuscous to black bar on each side of foramen, the mouth margin and malar sulcus fuscous. Antennal club with basal part paler than funicle, apex blackish, usually more than 3 times as long as broad; pedicel usually twice as long as wide.Mesoscutum 8-10 setae; delta are sometime not clearly separated from row of setae; propodeal crenulae elongate.

Abundance: The parasitism was observed for A. maculicornis on P.oleae infesting O.europaea at Alexandria. Maximum rate of parasitism reached 45 and $25 \%$ with means of 28.4 and $16.2 \%$ over 2013 and 2014, respectively. Dates of maximum activity were July 2013 and 2014. The seasonal activity of this parasitoid on P.oleae is presented in(Table,1and Fig. 4).

Data in Table (5), showed that the simple correlation between percent parasitism of parasitoid, $A$. maculicornis and the mean number of P.oleae were positive $(r=0.28280$ and 0.39344$)$ were non significant,during 2013 and 2014, respectively. On the other hand, results in Table (5), showed that the simple regression for changing the percent parasitism of parasitoid, $A$. maculicornis on the mean number of P.oleae were positive $(b=0.93$ and 1.35) were non significant, during 2013 and 2014, respectively.

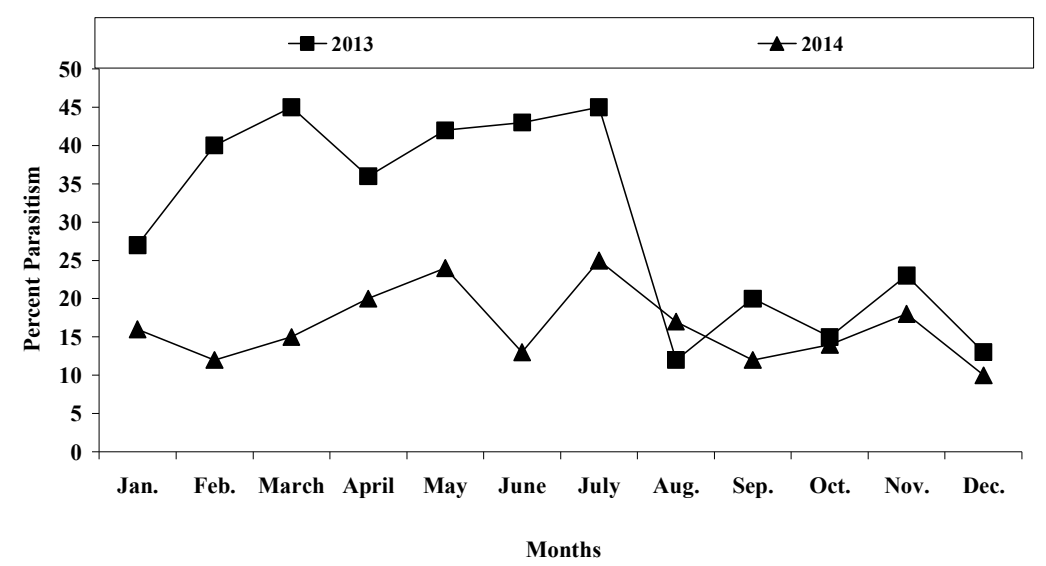

Fig. (4): Percent parasitism of Aphytis maculicornis associated with Parlatoria oleae infested olive in Alexandria during 2013 and 2014. . 
Table (5): Simple correlation and regression values of the population dynamics of insect and its parasitoids within 2013 and 2014.

\begin{tabular}{|l|c|c|c|c|}
\hline Variable & $\begin{array}{c}\text { Simple } \\
\text { correlation } \\
\text { "r" }\end{array}$ & $\begin{array}{c}\text { Probability } \\
\text { "P" }\end{array}$ & Regression & $\begin{array}{c}\text { Probability } \\
\text { "P" }\end{array}$ \\
\hline $\begin{array}{l}\text { Percent } \\
\text { parasitism. } \\
2013\end{array}$ & 0.28280 & 0.3731 & 0.93 & 0.3731 \\
\hline $\begin{array}{l}\text { Percent } \\
\text { parasitism. } \\
2014\end{array}$ & 0.39344 & 0.2058 & 1.35 & 0.2058 \\
\hline
\end{tabular}

Remarks: This species was recorded for the first time in Egypt by Priesner and Hosny (1940).

\section{Aphytis matruhi Abd-Rabou}

Diagnosis: Biparental species. Body yellow, thoracic setae paler. club 2.8 times as long as wide and 7 sensilla; parapsis 4 setae; axilla 2 setae; scutellum 4 setae; 1.6 times as long as propodeum; anteromedian apodeme robust, metanotum 1.1 times as long as apodeme. Forewing hyaline,2.6 times as long as wide, veins pale, marginal vein 12 setae, submarginal vein 2 setae, 18 bullae, delta 44 setae in 4 rows, marginal fringe 0.1 as long as width of disk. Basitarsus Ovipositor 1.9 times as long as midtibia.

Abundance: The parasitism was observed for $A$. matruhi on $H$. lataniae infesting O.europaea at Matruh. a Maximum rate of parasitism reached 35 and $22 \%$ with means of 21.9 and $14.8 \%$ over 2013 and 2014, respectively. Dates of maximum activity were May 2013 and November 2014 , respectively. The seasonal activity of this parasitoid on $H$. lataniae is presented in(Table,1and Fig. 5).

Data in Table (6), showed that the simple correlation between percent parasitism of parasitoid, $A$. matruhi and the mean number of $H$. lataniae were positive $(r=0.66877)$ during the first year $(2013)$ and were negative $(r=-0.37353)$ during the second year (2014) were non-significant, during 2013 and 2014, respectively. On the other hand, results in Table (6), showed that the simple regression for changing the percent parasitism of parasitoid, $A$. matruhi on the mean number of $H$. lataniae was positive with (b $=2.84)$ during 2013 and negative with $(b=-1.27)$ during 2014, were significant and non- significant, during 2013 and 2014, respectively. 


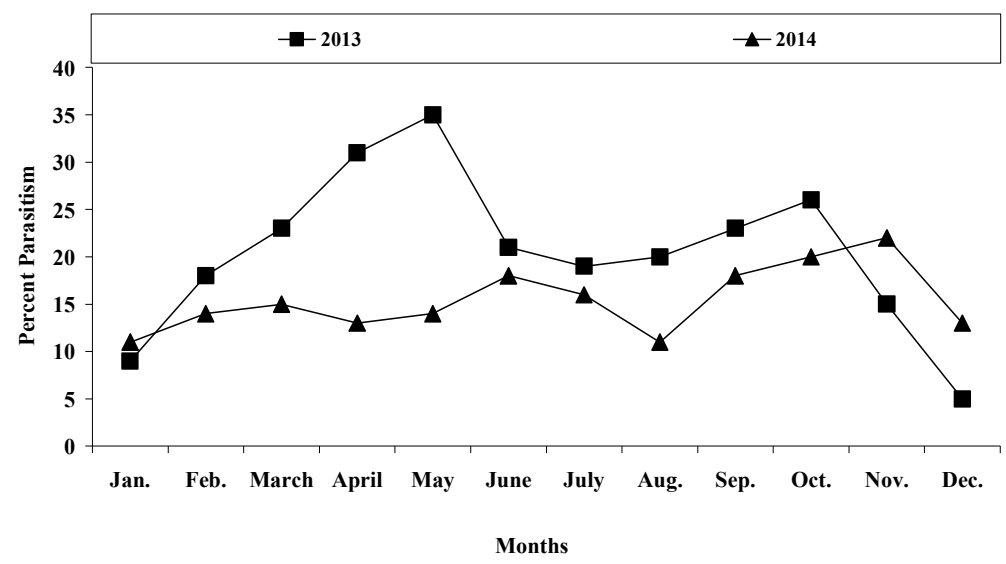

Fig. 5: Percent parasitism of Aphytis matruhi associated with Hemiberlesia lataniae infested olive in Matruh during 2013 and 2014. .

Table (6): Simple correlation and regression values of the population dynamics of insect and its parasitoids within 2013 and 2014.

\begin{tabular}{|l|c|c|c|c|}
\hline Variable & $\begin{array}{c}\text { Simple } \\
\text { correlation "r" }\end{array}$ & $\begin{array}{c}\text { Probability } \\
\text { "P" }\end{array}$ & Regression & $\begin{array}{c}\text { Probability } \\
\text { "P" }\end{array}$ \\
\hline $\begin{array}{l}\text { Percent } \\
\text { parasitism. } \\
2013\end{array}$ & 0.66877 & 0.0174 & 2.84 & 0.0174 \\
\hline $\begin{array}{l}\text { Percent } \\
\text { parasitism. } \\
2014\end{array}$ & -0.37353 & 0.2317 & -1.27 & 0.2317 \\
\hline
\end{tabular}

Remarks: Abd-Rabou (2004a) collected this species for the first time in Egypt.

Aphytis paramaculicornis De Bach \& Rosen

Diagnosis:This is biparental and solitary parasitoid species. Occiput with a fuscous to black bar on each side of foramen, the mouth margin and malar sulcus fuscous. Pedicel 1.8 times as long as wide, antennal club with basal part paler than funicle, apex of club usually about 3 times as long as broad; delta 130 setae in 10 rows and mesoscutum 14 setae.

Abundance: Only 53 individuals were collected associated with P.oleae in Alexandria during the two years under consideration (Table,1).

Remarks: This species was recorded for the first time in Egypt by AbdRabou and Hayat (2003). About 57000 individuals of A.paramaculicornis was released on olive trees infested by P.oleae in Northeren Coast, parasitism rates increased from $7 \%$ to $16 \%$ (Abd-Rabou, 2001e). 


\section{Coccophagoides aegypticus Abd-Rabou}

Diagnosis: Body dark brown, except antennae and coxae dark yellow, sensorial in female antennae only of F2 and last segment of club, scuteullum with 6 setae, marginal fringe 0.4 of wing of width, midtibial spur longer than basitarsus and ovipositor 1.9 as long as mid tibia.

Abundance: Only 21 individuals were collected associated with P.oleae in Alexandria during the two years under consideration (Table,1).

Remarks: This species described and recorded for first from Northern Coast associated that $P$. oleae on Olea sp. (Abd-Rabou,2013) .

Coccopagus cowperi Girault

Diagnosis: Hind tibia usually entirely yellowish, hind femur black, scutellum entirely yellow, anterior margin more or less black. Scutellum with three pairs of setae, rarely with a few extra setae near cephalic margin. Fore wing hyaline. All coxae usually black or blackish or at least partly so.

Abundance: Only 35 individuals were collected associated with Saissetia coffeae (Walker) (Hemiptera: Coccidae) in Matruh during the two years under consideration (Table,1).

Remarks :Abd-Rabou (2004b) impoted, mass reared and released this species for the first time in Egypt associated with $S$. coffeae.The hemispherical soft scale, $S$. coffeae is one of the most important pest attacking olive trees in Egypt. During the period 2001- 2003, a total of about 300000 individuals of the parasitoid, C. cowperi obtained from India was released at 35 sites for biological control of S.coffeae on olive trees in Egypt. The maximum parasitism rates by these individuals reached 53 and $62 \%$, while, average parasitism rates were 17.2 and $30.8 \%$ in Matruh and El-Arish locations, respectively. The results indicate the establishment of this parasitoid on this important economic insect pest in Egypt.

\section{Iycimnia (Walker)}

Diagnosis: Face and cheecks black to blackish brown thorax black except scutellum entirely or almost entirely yellowish or whitish; antenna 7 segmented $(1,1,3,2)$, first funicle segment longer than pedicel; stigmal vien not swollen, submarginal vien with a row at setae usually more than 5 setae; mesoscutum with numerous setae.

Abundance : The parasitism was observed for C. Iycimnia on Saissetia oleae (Olivier) (Hemiptera: Coccidae) infesting O.europaea at Alexandria. Maximum rate of parasitism reached 27 and $13 \%$ with means of 14.4 and 8.4 $\%$ over 2013 and 2014, respectively. Dates of maximum activity were May 2013 and 2014. The seasonal activity of this parasitoid on S. oleae is presented in (Table,1and Fig. 6).

Data in Table (7), showed that the simple correlation between percent parasitism of parasitoid, C. Iycimnia and the mean number of $S$. oleae were positive $(r=0.88882$ and 0.68563$)$ were highly significant and significant,during 2013 and 2014, respectively. On the other hand, results in Table (7), showed that the simple regression for changing the percent parasitism of parasitoid, $C$. lycimnia on the mean number of $S$. oleae were positive ( $b=6.13$ and 2.98 ) were highly significant and significant, during 2013 and 2014, respectively. 


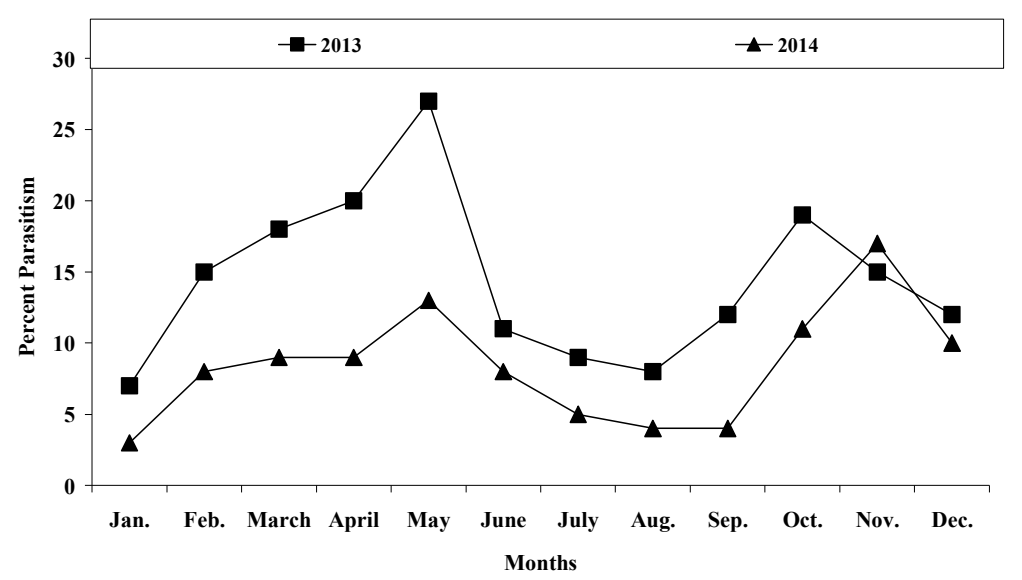

Fig. (6): Percent parasitism of Coccophagus lycimnia associated with Saissetia oleae infested olive in Alexandria during 2013 and 2014.

Table (7): Simple correlation and regression values of the population dynamics of insect and its parasitoids within 2013 and 2014.

\begin{tabular}{|l|c|c|c|c|}
\hline Variable & $\begin{array}{c}\text { Simple } \\
\text { correlation } \\
\text { "r" }\end{array}$ & $\begin{array}{c}\text { Probability } \\
\text { "P" }\end{array}$ & Regression & $\begin{array}{c}\text { Probability } \\
\text { "P” }\end{array}$ \\
\hline $\begin{array}{l}\text { Percent } \\
\text { parasitism. } \\
2013\end{array}$ & 0.88882 & 0.0001 & 6.13 & 0.0001 \\
\hline $\begin{array}{l}\text { Percent } \\
\text { parasitism. } \\
2014\end{array}$ & 0.68563 & 0.0138 & 2.98 & 0.0138 \\
\hline
\end{tabular}

Remarks: This species was collected for the first time in Egypt associated with Coccus hesperidum Linnaeus (Hemiptera: Coccidae) by Abd-Rabou et al. (1999). C. Iycimnia one of the most effective parasitoids associated with S. oleae in different localities in Egypt ( Abd-Rabou, 2001a). Also C. Iycimnia appeared to be quite important parasitoids of S.coffeae in Alexandria and Northern Coast with average parasitism rates of 8.3 and $10.8 \%$ and the maximum parasitism rates were 28 and $26 \%$ during November in Northern Coast and Alexandria, respectively (Abd-Rabou, 2001c).

\section{C. scutellaris (Dalman)}

Diagnosis: Scutellum with numerus setae, fore coxa yellow. First funicle segment more than twice as long as wide and first club segment longer than wide. 
Abundance: The parasitism was observed for $C$. scutellaris on $S$. oleae infesting O.europaea at Assuit. Maximum rate of parasitism reached 28 and $23 \%$ with means of 14.2 and $16.0 \%$ over 2013 and 2014, respectively. Dates of maximum activity were November 2013 and 2014. The seasonal activity of this parasitoid on S. oleae is presented in (Table,1and Fig. 7).

Data in Table (8), showed that the simple correlation between percent parasitism of parasitoid, $C$. scutellaris and the mean number of $S$. oleae were positive $(r=0.26711$ and 0.40868$)$ were non significant, during 2013 and 2014, respectively. On the other hand, results in Table (8), showed that the simple regression for changing the percent parasitism of parasitoid, $C$. scutellaris on the mean number of $S$. oleae were positive $(b=0.88$ and 1.42$)$ were non significant, during 2013 and 2014, respectively.

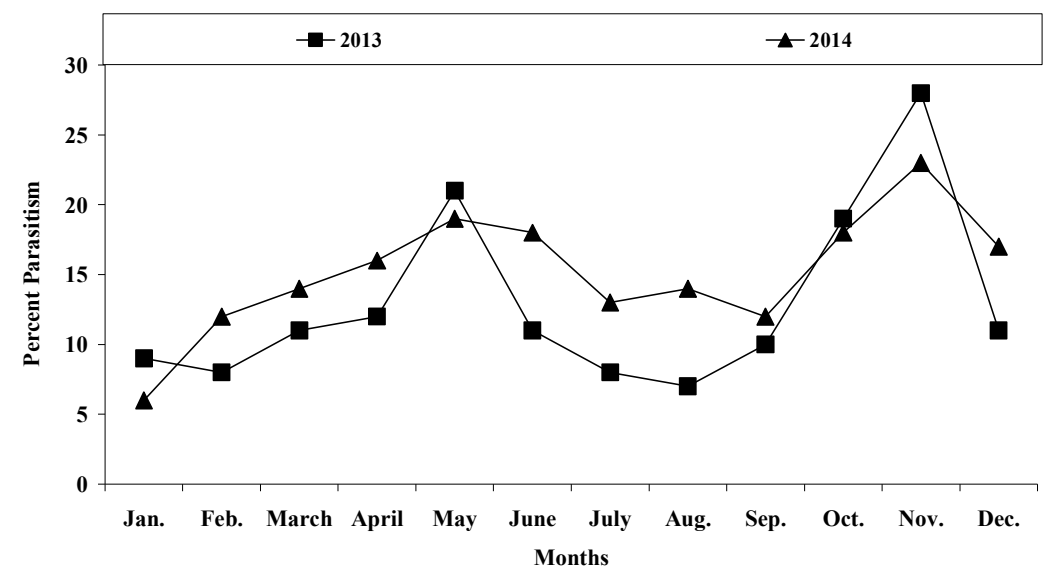

Fig. (7): Percent parasitism of Coccophagus scutellaris associated with Saissetia oleae infested olive in Assuit during 2013 and 2014.

Table (8): Simple correlation and regression values of the population dynamics of insect and its parasitoids within 2013 and 2014.

\begin{tabular}{|l|c|c|c|c|}
\hline Variable & $\begin{array}{c}\text { Simple } \\
\text { correlation “r" }\end{array}$ & $\begin{array}{c}\text { Probability } \\
\text { “P” }\end{array}$ & Regression & $\begin{array}{c}\text { Probability } \\
\text { "P" }\end{array}$ \\
\hline $\begin{array}{l}\text { Percent } \\
\text { parasitism. } \\
2013\end{array}$ & 0.26711 & 0.4013 & 0.88 & 0.4013 \\
\hline $\begin{array}{l}\text { Percent } \\
\text { parasitism. } \\
2014\end{array}$ & 0.40868 & 0.1872 & 1.42 & 0.1872 \\
\hline
\end{tabular}

Remarks: This species collected for the first time in Egypt by Priesner and Hosny (1940). This species is one of the best known species of the family Aphelinidae. C.scutellaris recorded in Alexandria by Priesner and Hosny 
(1940) parasitizing C. hesperidum . and Pulvinaria floccifera (Westwood) on Citrus sp. and Ficus sp., respectively. Recently Abd-Rabou (2002) recorded this species attacking 6 species of soft scales, mentioned that the maximum parasitism rates of this species on $S$. coffeae and $S$. oleae reached 26 and $22 \%$, respectively. Abd-Rabou et al.( 1999) found it in Gharbiya, where the percentage parasitism on P.guajava was $1.1 \%$, with a peak of $7 \%$ in Nov.

Encarsia aurantii (Howard)

Diagnosis: Face without dark brown cross bands above the toruli, gaster except apex of T7, largely brown to dark brown. Side lobes of mesoscutum each with two or fewer setae. Antennal club 3-segmented, ovipositor very short, clearly much shorter than mid tibia.

Abundance: The parasitism was observed for $E$. aurantii on P.oleae infesting $O$. europaea at Alexandria. Maximum rate of parasitism reached 35 and $34 \%$ with means of 10.8 and $10.8 \%$ over 2013 and 2014, respectively. Dates of maximum activity were May 2013 and November 2014. The seasonal activity of this parasitoid on P.oleae is presented in (Table,1and Fig. 8).

Data in Table (9), showed that the simple correlation between percent parasitism of parasitoid, $E$. aurantii and the mean number of $P$.oleae were positive $(r=0.41186)$ during 2013 and negative with $(r=-0.37763)$ during 2014 were non significant, during 2013 and 2014, respectively. On the other hand, results in Table (9), showed that the simple regression for changing the percent parasitism of parasitoid, $E$. aurantii on the mean number of $P$.oleae were positive $(b=1.43)$ during 2013 and negative with $(b=-1.9)$ during 2014 were non significant, during 2013 and 2014, respectively.

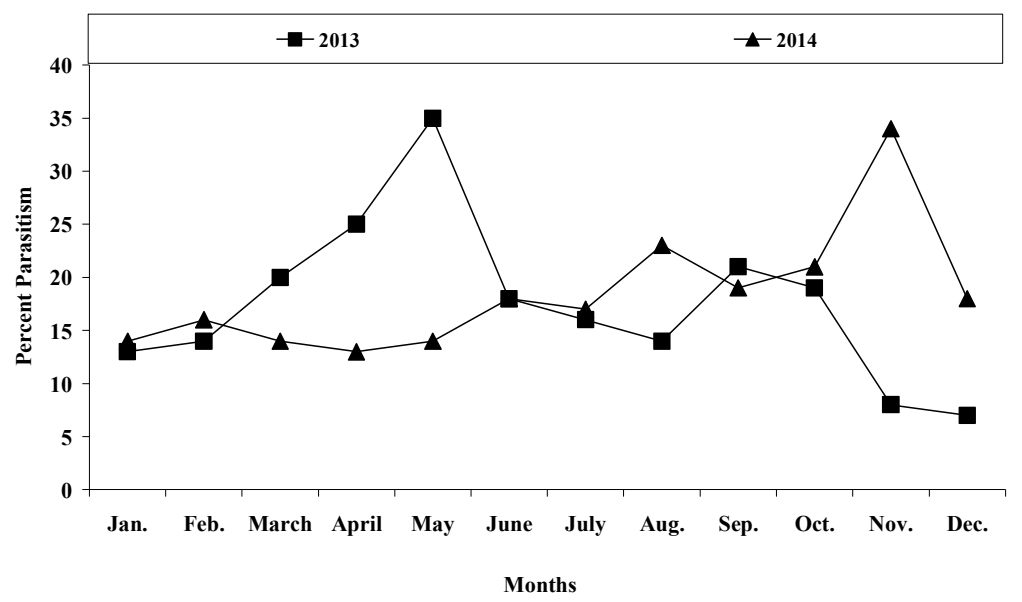

Fig. (8): Percent parasitism of Encarsia aurantii associated with Parlatoria oleae infested olive in Alexandria during 2013 and 2014. 
Table (9): Simple correlation and regression values of the population dynamics of insect and its parasitoids within 2013 and 2014.

\begin{tabular}{|l|c|c|c|c|}
\hline Variable & $\begin{array}{c}\text { Simple } \\
\text { correlation "r" }\end{array}$ & $\begin{array}{c}\text { Probability } \\
\text { "P" }\end{array}$ & Regression & $\begin{array}{c}\text { Probability } \\
\text { "P" }\end{array}$ \\
\hline $\begin{array}{l}\text { Percent } \\
\text { parasitism. } \\
2013\end{array}$ & 0.41186 & 0.1834 & 1.43 & 0.1834 \\
\hline $\begin{array}{l}\text { Percent } \\
\text { parasitism. } \\
2014\end{array}$ & -0.37763 & 0.2262 & -1.29 & 0.2262 \\
\hline
\end{tabular}

Remarks: This species was recorded for the first time in Egypt by Hafez (1988). About 44000 individuals of $E$. aurantii was released on olive trees infested by P.oleae in Northeren Coast, the parasitism rates increased from $44 \%$ to $71 \%$ (Abd-Rabou, 2001e).

\section{Encarsia citrina (Craw)}

Diagnosis: Body largely pale. Longest seta on marginal fringe of fore wing less than the maximum wideth of wing disc. Submarginal vein of fore wing with 2 setae.

Abundance: The parasitism was observed for $E$. citrina on $L$. riccae infesting O.europaea at Fayoum. Maximum rate of parasitism reached 12 and $9 \%$ with means of 5.3 and $2.5 \%$ over 2013 and 2014, respectively. Dates of maximum activity were May 2013 and November 2014. The seasonal activity of this parasitoid on P.oleae is presented in (Table,1and Fig. 9).

Data in Table (10), showed that the simple correlation between percent parasitism of parasitoid, $E$. citrina and the mean number of $L$. riccae were positive $(r=0.05991$ and 0.21467$)$ were non significant, during 2013 and 2014 , respectively. On the other hand, results in Table (10), showed that the simple regression for changing the percent parasitism of parasitoid, $E$. citrina on the mean number of $L$. riccae were positive $(b=0.19$ and 0.70$)$ were non significant, during 2013 and 2014, respectively. 


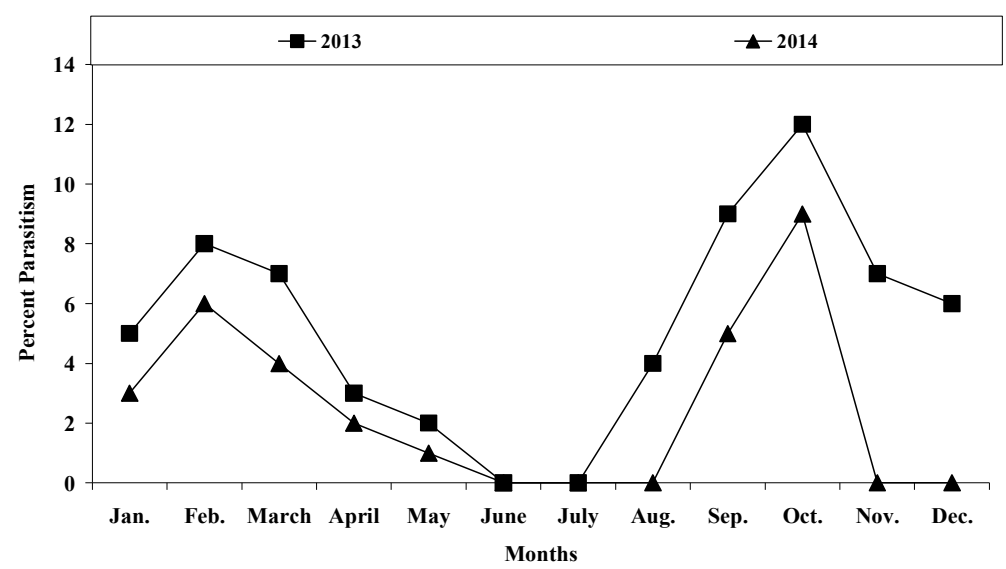

Fig. (9): Percent parasitism of Encarsia citrina associated with Leucaspis riccae infested olive in Fayoum during 2013 and 2014.

Table (10): Simple correlation and regression values of the population dynamics of insect and its parasitoids within 2013 and 2014.

\begin{tabular}{|l|c|c|c|c|}
\hline Variable & $\begin{array}{c}\text { Simple correlation } \\
\text { "r" }\end{array}$ & $\begin{array}{c}\text { Probability } \\
\text { "P" }\end{array}$ & Regression & $\begin{array}{c}\text { Probability } \\
\text { "P" }\end{array}$ \\
\hline $\begin{array}{l}\text { Percent } \\
\text { parasitism. } \\
2013\end{array}$ & 0.05991 & 0.8533 & 0.19 & 0.8533 \\
\hline $\begin{array}{l}\text { Percent } \\
\text { parasitism. } \\
2014\end{array}$ & 0.21467 & 0.5028 & 0.70 & 0.5028 \\
\hline
\end{tabular}

Remarks: This species was recorded for the first time in Egypt by Priesner \& Hosny (1940). Abd-Rabou (1997) mentioned that E. citrina should be considered a promising candidate for utilization in biological control of armored scale insects in Egypt. This species was reared from 8 species of diaspidid scale insects and maximum parasitism rates ranged between 23 and $65 \%$.

\section{Encarsia inaron (Walker)}

Diagnosis: Head, thorax and gaster brown to black. Female with antennal club 2-segmented. Mesoscutum 12 setae. Stigmal vein of fore wing without an evident a setose area proximally. At least one small seta proximal to the stigmal vein. F1 with at least one longitudinal sensillum. Male antenna 8segmented. Fifth and sixth funicular segments of male antenna separate.

Abundance: The parasitism was observed for $E$. inaron on S. phillyreae infesting O.europaea at Fayoum. Maximum rate of parasitism reached 58 and $39 \%$ with means of 38.9 and $23.3 \%$ over 2013 and 2014, respectively. Dates of maximum activity were May 2013 and November 2014. The seasonal 
activity of this parasitoid on S. phillyreae is presented in (Table,1and Fig. 10).

Data in Table (11), showed that the simple correlation between percent parasitism of parasitoid, $E$. inaron and the mean number of $S$. phillyreae were positive $(r=0.68318$ and 0.38675$)$ were significant and nonsignificant,during 2013 and 2014, respectively. On the other hand, results in Table (11), showed that the simple regression for changing the percent parasitism of parasitoid, $E$. inaron on the mean number of $S$. phillyreae were positive $(b=2.96$ and 1.33) were significant and non-significant, during 2013 and 2014, respectively.

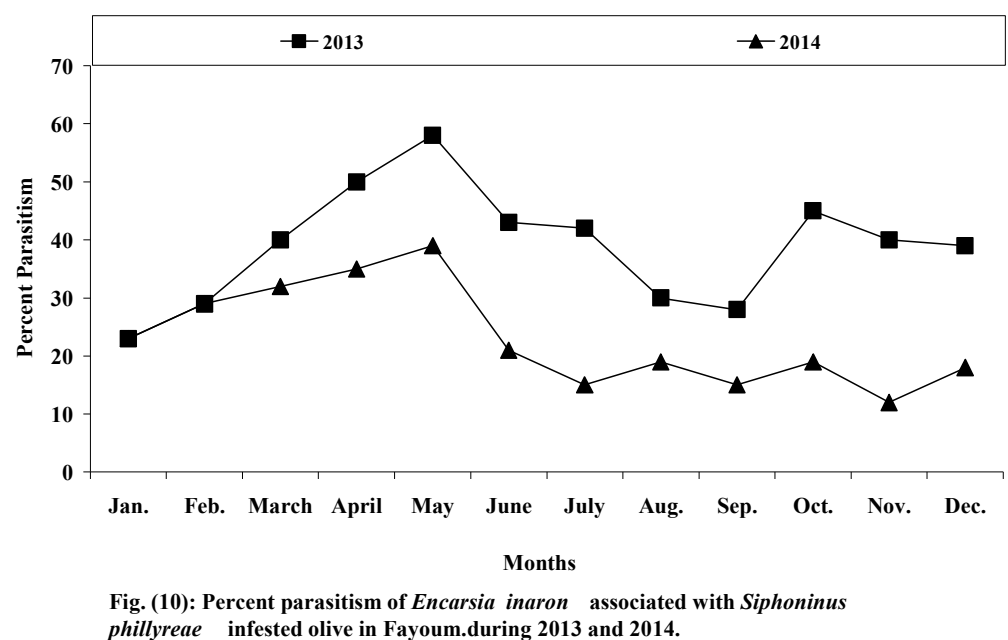

Table (11): Simple correlation and regression values of the population dynamics of insect and its parasitoids within 2013 and 2014.

\begin{tabular}{|l|c|c|c|c|}
\hline Variable & $\begin{array}{c}\text { Simple } \\
\text { correlation "r" }\end{array}$ & $\begin{array}{c}\text { Probability } \\
\text { "P" }\end{array}$ & Regression & $\begin{array}{c}\text { Probability } \\
\text { "P" }\end{array}$ \\
\hline $\begin{array}{l}\text { Percent } \\
\text { parasitism. } \\
2013\end{array}$ & 0.68318 & 0.0143 & 2.96 & 0.0143 \\
\hline $\begin{array}{l}\text { Percent } \\
\text { parasitism. } \\
2014\end{array}$ & 0.38675 & 0.2143 & 1.33 & 0.2143 \\
\hline
\end{tabular}

Remarks: This species was recorded for the first time in Egypt by Priesner \& Hosny (1940). Abd-Rabou (1998) concluded that the parasitoid E. inaron has some potential for suppressing population of $S$. phillyreae on pomegranate. Later Abd-Rabou (2001d) recorded two strains of E. inaron in Egypt and he 
reared, released and evaluated these strains on Punica granatum and Ricinus communis in different localities in Egypt.

E. olivina (Masi)

Diagnosis: Gaster mostly blackish, antenna with narrow scape, about 4 times as long as wide, second and third funicle segments subcylindrical each about twice as long as wide, club 3-segmented, about 1/5 longer and slightly wide than funicle, each segment about as long as third funicle segment.

Abundance: Only 30 individuals were collected associated with $A$. olivinus in Fayoum during the two years under consideration (Table,1).

Remarks: This species was recorded for the first time in Egypt by Abd-Rabou (1999).

\section{Marietta leopardina Motschulsky}

Diagnosis: Antennal scape less than 6 times as long as wide, or with one or two brownish bands or spots; anntennal scape with the band short; extending cauded from about middle of ventral margin; propodeum distinctly shorter than, metanotum; apex of fore wing without infuscate band in middle, mesoscutum 4 setae.

Abundance: Only 25 individuals were collected associated with $H$. lataniae in Ismailia during the two years under consideration(Table,1).

Remarks: This species was recorded for the first time in Egypt by Priesner and Hosny (1940). This species is a hyperparasitoids of different species of armored and soft scale insects in Egypt (Abd-Rabou, 2003c). He mentioned that M.leopardina was reared out of 48 Hemiptera and scales parasitic Hymenoptera species. The survey covered 16 governorates in Egypt. Classically orders, families and species of the host insects associated with this hyperparasitoid are given together with locality and month of abundance.

\section{REFERENCES}

Abd-Rabou, S. (1996): Egyptian Aleyrodidae. Acta Phytopathologica et Entomologica Hungarica, 31 (3-4): 275-285.

Abd-Rabou, S. (1997): The role of Encarsia citrina (Hymenoptera: Aphelinidae) in the biological control of armored scale insects (Homoptera: Coccoidea: Diaspididae) in Egypt. Proceeding of the First Scientific Conference of Agricultural Sciences, Faculty of Agric. Assiut Univ., Vol. II,711-717.

Abd-Rabou, S. (1998): The efficacy of indigenous parasitoids in the biological control of Siphoninus phillyreae (Homoptera: Aleyrodidae) on pomegranate in Egypt. Pan-Pacific Entomolgists, 74 (3): 169-173.

Abd-Rabou, S. (1999): Newly recorded of aphelinids and encyrtids in Egypt. Egypt. J. Agric. Res. 78 (5): 1915-1924.

Abd-Rabou, S. (2000): Aphytis chrysomphali (Hymenoptera : Apheinlidae) as an effective parsitoids of armored scale inestcs in Egypt. Poster Presentation $\left(26^{\text {th }}\right.$ October $)$ Seventh Arab Congress of Plant Protection. 
Abd-Rabou, S. (2001a): Biological control of the Mediterranean black scale Saissetia oleae (Olivier) (Hemiptera: Coccidae) on olive in Egypt. Bollettino-di-Zoologia-Agraria-e-di-Bachicoltura. 33(3): 483.

Abd-Rabou, S. (2001b): Whiteflies of Egypt : Taxonomy, biology, ecology and means of their control. Adv. Agric. Res. In Egypt, Vol. 3 (1): 1-74.

Abd-Rabou, S. (2001c): A survey of parasitoids associated with the hemispherical scale, Saissetia coffeae (Walker) (Hemiptera : Coccidae) in North-west Coastal area of Egypt. Bull. Fac. Agric. Cairo, Univ. Special Edition, 1-5.

Abd-Rabou, S. (2001d): Efficacy of different parasitoid strains of Encarsia inaron (Hymenoptera : Aphelinidae) in biological control of whiteflies (Hemiptera: Aleyrodidae) in Egypt. First Conference of Safe Alternatives of Pesticides for Pest Management, Assiut Univ. 235-242.

Abd-Rabou, S. (2001e): The effect of augementitive releases of indigenous parasitoids on population of parlatoria oleae (Clovee')(Homoptera : coccidea ) in olive groves in Egypt . Boll. Zool. Agr. Bachic, 33(3): 473481.

Abd-Rabou, S. (2002): The role of Coccophagus scutellaris (Hymenoptera:Aphelinidae) in the biological control of soft scale insects (Homoptera: Coccidae) in Egypt. Species (Homoptera : Aleyrodidae) in Egypt. Entomologia Sinica ,Vol. (3): 39-44.

Abd-Rabou, S. (2003a): Scale insects and their management in Egypt. Adv. Agric. Res. In Egypt, Vol. (4) 1: 1-63.

Abd-Rabou, S. (2003b): First record of pomegranate whitefly, Siphoninus phillyreae ( Haliday) (Homoptera : Aleyrodidae) on olive in North Sinai, Egypt. Egypt. J. of Agric. Res. 81(4): 1577-1579.

Abd-Rabou, S. (2003c): Host range and distribution of Marietta leopardina (Hymenoptera: Aphelinidae), a hyperparasitoid of hemipterous and hymenopterous species in Egypt. Egyptian, J. of Agric. Res.81(2): 555562.

Abd-Rabou, S. (2004a): Revision of the genus Aphytis (Aphelinidae: Hymenoptera) with discriptions of two new species from Egypt. Entomologia Sinica, Vol.11(2):149-164.

Abd-Rabou, S. (2004b): Importation, colonization and establishment of Coccophagus cowperi(Hymenopetra: Aphelinidae) on Saissetia coffeae (Homopetra: Coccidae) in Egypt. J.Pest Sci. 78:77-81.

Abd-Rabou, S. (2013): Coccophagoides Girault (Hymenoptera: Aphelinidae) of Egypt with new species, Coccophagoides aegypticus Abd-Rabou sp.nov. International Journal of Fauna and Biological Studies, 1 (1): 3941.

Abd-Rabou, S. (2014): Ablerus Howard ( Hymenoptera : Aphelinidae) of Egypt With New Species, Ablerus aegypticus Abd-Rabou sp.nov. International Journal of Fauna and Biological Studies , 1 (5): 10-12.

Abd-Rabou, S. and Hayat, M. (2003): A synopsis and key to the Egyptian species of Aphytis Howard (Hymenoptera : Aphelinidae) parasitoids of diaspidid scale insects (Homoptera : Diaspididae). Acta Phytopathologica et Entomologica Hungarica, Vol. 38(3-4):357-363. 
Abd-Rabou, S.; Hanafi, A. and Hussein, N. (1999): Notes on the parasitoids of the soft brown scale, Coccus hesperidum (Hemiptera: Coccidae) in Egypt. Entomologica, Bari, 33: 179-184.

Dreistadt, S.H.; Flint, M.L. and Clark, J.K. (2004): Pests of landscape trees and shrubs: an integrated pest management guide. 2nd ed. Oakland: Univ. Calif. Agric. Nat. Res. Publ. 3359.

Gill, R. J. (1997): The Scale Insects of California Parts 1-3. Sacramento: Calif. Dept. Food Agric.

Hafez, M. (1988): Population fluctuations on parasites of California red scale, Aonidiella aurantii (Mask) (Homoptera : Diaspididae) in Alexandria. J. App. Ent., 106 (2): 183-187.

Priesner, A. and Hosny, M. (1940): Notes on parasites and predators of Coccidae and Aleyrodidae in Egypt. Bull. Soc. Ent. Egypte, 24: 58-70.

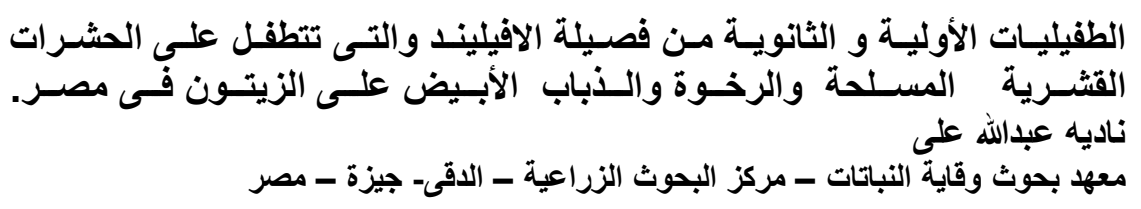

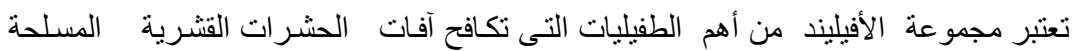

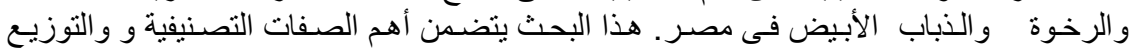

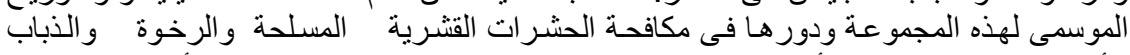

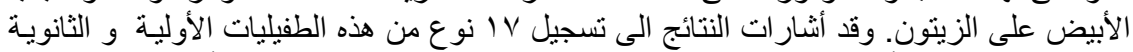

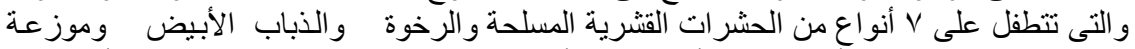

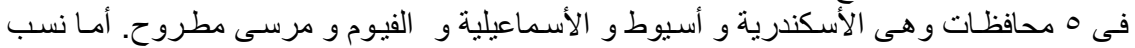

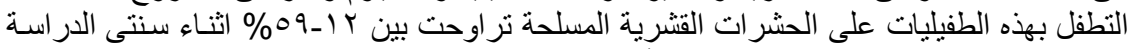

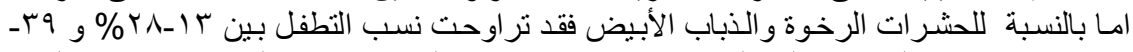

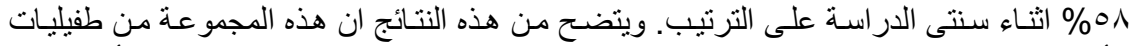

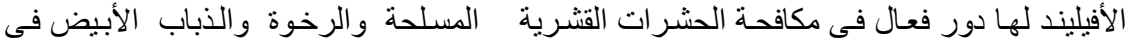


Nadia A. Aly 


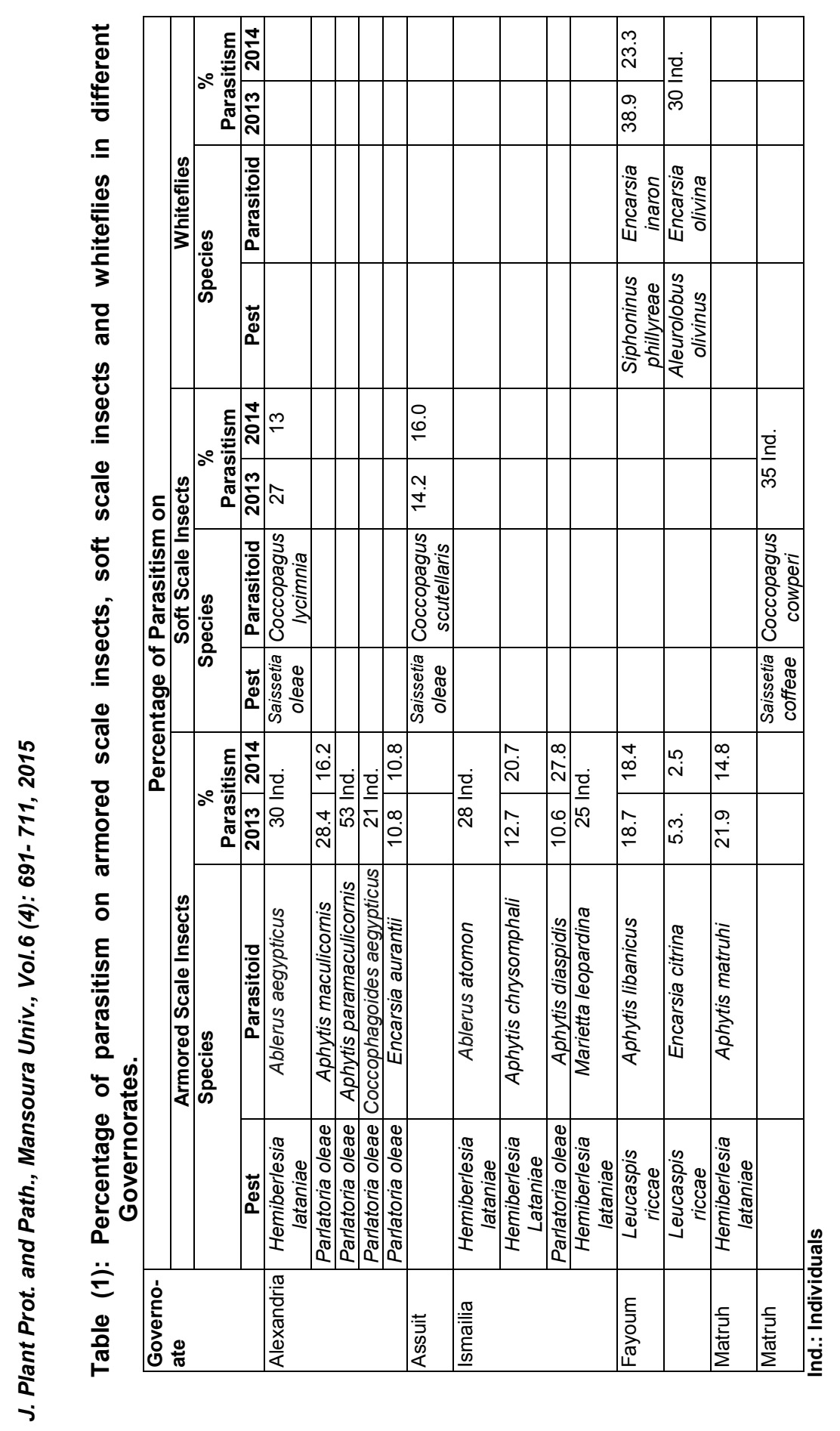


$\frac{1}{\pi}$

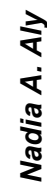

